\title{
How COVID-19's Disruption of the U.S. Correctional System Provides an Opportunity for Decarceration
}

\author{
Leola A. Abraham ${ }^{1} \cdot$ Timothy C. Brown $^{2}$ (D) Shaun A. Thomas ${ }^{3}$ \\ Received: 10 May 2020 / Accepted: 29 May 2020 / \\ Published online: 19 June 2020 \\ (C) Southern Criminal Justice Association 2020
}

\begin{abstract}
The COVID-19 pandemic has amplified decades of vulnerabilities, disparities, and injustices within the U.S. correctional system. The spread of the coronavirus poses a particularly serious threat to those that comprise the system, including personnel, attorneys, prisoners, their families and extends into the communities in which facilities are located. These correctional facilities and communities were especially underprepared for the sudden onset of a highly contagious virus, which has resulted in an exceedingly high number of infections among those who work and are held in the facilities. Rampant overcrowding in the U.S. correctional system, an aging population, and a population exhibiting high rates of underlying health conditions are highly likely to exacerbate the spread of this highly contagious virus. This potentially dire set of interrelated circumstances necessitates rapid decarceration measures that effectively balance public safety and public health. Unfortunately, there has been unclear guidance as well as changing and even contradictory information coming from the federal government concerning rapid measures to mitigate the spread of infection to justice system personnel and federal prisoners. In this paper we summarize the federal response and how it has impacted those responsible for implementation. Furthermore, we discuss how systemic deleterious conditions of the U.S. correctional system serve as both accelerants to as well as effects of the pandemic. We end highlighting critical issues relating to early release due to COVID-19 that will necessitate future research.
\end{abstract}

Keywords COVID-19 · Early release $\cdot$ Mass incarceration

Timothy C. Brown

Tbrown3@sdsu.edu

Leola A. Abraham

labraham@american.edu

Shaun A. Thomas

shaun@uark.edu

Extended author information available on the last page of the article 


\section{Introduction}

As the novel coronavirus (COVID-19) pandemic unfolds across the globe, the United States (U.S.) has become one of the primary epicenters of the crisis. Most countries were caught off-guard by the seemingly sudden onset of COVID-19 as well as the rapid transmission rate of the virus. Many hospitals around the world are at, near, or exceeding their maximum capacity while the global economy has nearly ground to a halt. In the U.S., individuals, communities, and the social institutions at the core of our society were woefully underprepared for a pandemic. At this writing, there have been more than 2.1 million confirmed cases of COVID-19 and 116,000 deaths from the virus, in the U.S. (Johns Hopkins University of Medicine 2020). The U.S. death toll has now surpassed all other countries and may exceed the number of Americans lost in the Korean, Vietnam, Afghanistan, and Iraq wars combined (Abutaleb et al. 2020).

Disruptions linked to the COVID-19 pandemic threaten virtually all U.S. social institutions. The crisis is highlighting cracks in these institutions by shedding light on systemic vulnerabilities and disparities. Moreover, the increased pressure on some systems is exacerbating long standing flaws and leading to systemic failures. For example, the crisis threatens to overwhelm the public healthcare system and is revealing significant disparities in the population's access to healthcare. The crisis has also placed tremendous strain on financial and economic institutions as National Social Distancing Guidelines and State Stay-At-Home Orders disrupt business, leading to historic levels of unemployment.

The U.S. corrections system is another institution for which the ramifications of the COVID-19 pandemic are particularly pronounced. The U.S. has the highest incarceration rate in the world, at 698 per 100,000 residents. There are currently more than 2.3 million individuals incarcerated in the U.S., including approximately 1.3 million in state prisons, 630,000 in local jails, and 225,000 in federal prisons and jails. To put these numbers into perspective, the U.S. has $5 \%$ of the world's population but a quarter of its prisoners. The epidemic of mass incarceration in the U.S. has served to exacerbate the COVID-19 health pandemic (Sawyer and Wagner 2020).

The COVID-19 pandemic has amplified decades of vulnerabilities, disparities, and injustices within the U.S. criminal justice system. Decades of draconian legislation, harsh sentencing, and mass incarceration have resulted in today's overcrowded prison system. These measures have also had a disproportionate impact on minorities and minority communities. In particular, African Americans are overrepresented at virtually all points within the criminal justice system (Armstrong and Rodriguez 2005; Bridges and Steen 1998; Leiber 2013; Puzzanchera and Adams 2012; Thomas et al. 2013).

\section{Pressure on an Already Overwhelmed System}

The spread of the virus poses a particularly serious threat to those involved in our corrections system, including prisoners, staff, their families, and the communities in which correctional facilities are located. These facilities and communities were particularly underprepared for the sudden outbreak of a highly contagious virus, which has resulted in an exceedingly high number of infections among those who work and are held in correctional facilities. Correctional facilities, by their very nature, can serve as amplifiers of a highly contagious virus as they are designed to keep a large number of 
people in close or confined quarters. Further, rampant overcrowding in the U.S. correctional system (Alexander 2012; Guetzkow and Schoon 2015) is likely to exacerbate the spread of an already highly contagious virus. For example, there is evidence linking cell spatial density to infectious diseases (Simpson et al. 2019). In fact, "health officials have been warning for more than a decade about the dangers of outbreaks in jails and prisons, which are ideal environments for virus outbreaks" (Lauer and Long 2020). Overcrowded spaces make it practically impossible to implement even the most rudimentary social distancing practices and could turn into a tinderbox for those who work and are held in the system.

Further complicating matters, the incarcerated population is aging and exhibits overall high rates of underlying health conditions, key factors that have been identified as making individuals more susceptible to being infected and increasing the likelihood of severe symptoms and outcomes, including mortality (CDC, 2020a). Decades of tough sentencing laws and punitive measures have led to a "gray wave" — an aging crisis in our prisons. Indeed, older incarcerated individuals comprise the fastest growing demographic in the U.S. prison system (Skarupski et al. 2018). Moreover, the number of older federal prisoners is growing at a faster rate than the total federal prison population (McKillop and Boucher 2018).

In addition to housing an aging population, chronic health conditions are particularly prevalent among incarcerated populations compared to the general population (Binswanger et al. 2009; Fazel and Baillargeon 2011). In a study of 759 recently admitted inmates from two New York State prisons, 34\% were found to have respiratory illnesses (Bai et al. 2015). These chronic illnesses serve to exacerbate the at-risk status of the incarcerated population since they often mirror those that have been found to be particularly problematic in combination with COVID-19.

It is also imperative to consider the poor level of general hygiene and sanitation practices available in most correctional facilities, which are particularly critical in an environment in which social distancing is impractical. Centers for Disease Control and Prevention (CDC) recommendations have underscored the value of sanitary conditions in living environments as a practical prevention to contracting the coronavirus (CDC, 2020b). Unfortunately, conditions in prisons and jails do not offer safe environments for inmates or staff. In fact, America's prisons and jails have long been criticized for unsanitary conditions with some even referring to them as "petri dishes" (Williams et al. 2020).

Further complicating matters, the required movement of inmates and staff has made correctional facilities especially risky places conducive to "community spread" both within and external to the facility. While the public perceives prisons as closed environments, the virus can enter a facility when a new prisoner is introduced or the virus can travel from visits from family, friends, attorneys, etc. In addition to quickly overwhelming the healthcare capacity of the correctional facility, a COVID-19 outbreak in a facility exposes staff to the virus. It is exceedingly difficult to contain the virus within the prison complex as prison staff and other service providers return home after their shifts or visits and engage in the community, thereby increasing the risk of a virus outbreak in the local community. This potentially dire set of interrelated circumstances makes it imperative to implement rapid decarceration measures that effectively balance public safety and public health. 
Federal, state, and local correctional institutions have scrambled to respond to the COVID-19 crisis in such a way that balances public safety and health while ensuring the safety of prisoners and staff. Under normal circumstances, prisoners being considered for early release are assessed using risk assessment tools that have been rigorously evaluated. These tools are implemented at predetermined intervals and there is often a focus on determining the barriers individuals will face upon return to the community as well as the services and resources they will need for successful reentry. This process can, however, be painstakingly slow and is not easily adaptable to a situation such as the current one, which necessitates rapid decarceration. Making matters worse, the federal government has issued ambiguous guidance as well as fluctuating and contradictory information concerning what the best course of action is in terms of both protecting against the virus entering a facility and, more importantly, best practices for preparing for and taking action once the virus is confirmed in a facility. By and large, most correctional facilities are focusing their efforts on keeping the virus from entering, which appears to be a rather futile effort based on recent outbreaks in federal (e.g. FCI Terminal Island in Los Angeles) and state facilities (e.g. Arkansas Cummins Unit). Another solution many facilities have explored is the development of compassionate release guidelines for inmates who are particularly vulnerable to the virus, pose a low risk to public safety, and/or have not been formally convicted of the offense for which they are being held. Although there is agreement among most politicians, practitioners, researchers, and laypeople that public safety must be the prime concern, thoughtful release policies have the potential to save lives now and offer a chance to explore how massdecarceration might work under different circumstances. A few jails that are rapidly decarcerating include, Charles County, Maryland; Los Angeles County, California; and Maricopa County, Arizona. Each has decreased its jail population by about $30 \%$ in two months or less.

To be sure, there are no easy answers as to what the best course of action is when it comes to quickly making decisions on the release of a vast number of inmates. Even under normal times, more than 600,000 individuals are released from prisons and jails annually (Carson and Golinelli 2014) and millions more are already under community supervision. Moreover, many individuals are being released into communities that have excessively high unemployment rates and a scarcity of services that are critical to successful reentry. There has been a wide variety of responses across our local, state, and federal correctional systems. Arkansas is allowing some COVID-19 positive staff members who are not presenting with symptoms to continue to work (Gill 2020) while many other facilities are taking unprecedented measures to stop the spread of the virus. Colorado and Illinois have issued orders refusing to admit new inmates into state prisons and Mississippi suspended in-person check-ins for those on any form of community supervision. Although most states continue to test relatively few inmates for the virus, some have pushed to test every inmate, even those who are asymptomatic (Aspinwall and Neff 2020). Such practices led particular units, such as the Arkansas Cummins unit, to appear as if they have among the highest rates of infection. However, it remains unclear if the elevated rate of positive tests is the result of increased spread or widespread testing. 


\section{An Unclear Federal Response}

As COVID-19 infections and deaths rose in state and federal prisons, jails, and detention centers (Park et al. 2020), stakeholders (e.g. congressional representatives, attorneys, and advocates) citing overcrowding and poor sanitary conditions, championed the early release of populations at high risk of contracting the virus. The U.S. Department of Justice (DOJ) has the statutory authority to take measures to mitigate the spread of infection to justice system personnel and federal prisoners. The Coronavirus Aid, Relief, and Economic Security Act (CARES Act) (U.S. Congress 2020), gave the DOJ and the federal Bureau of Prisons (BOP) greater authority to release high-risk prisoners to home confinement; The First Step Act (Sullivan 2018) increased the availability of compassionate release; and the Bail Reform Act (BRA) (Adair Jr. 2006), has a pretrial release provision. In responding to the COVID-19 pandemic, the BOP implemented the BOP COVID-19 Action Plan (BOP, 2020a). In addition, U.S. Attorney General William Barr issued memorandas to the BOP that provided guidance on how the department should implement its statutory authorities to respond to the crisis, including focusing on early release to home confinement for those who met certain conditions.

The guidance necessitated clear communications in order to be understood and to be effective. During the course of an emergency or crisis, well-conceived and effectively delivered messages to stakeholders and impacted communities can help ensure public safety and instill public confidence. Furthermore, any messages should be clear and accessible, contain specific and adequate information, and be coordinated among agencies (FEMA 2014). In assessing BOP's communications during the COVID-19 pandemic, however, stakeholders have described the guidelines and response as lacking transparency on the handling of the crisis and lacking prompt, accurate reporting of numbers of those infected and of fatalities. Concerning the criteria for early release to home confinement, stakeholders described it as confusing and conflicting with "shifting, contradictory" criteria (Satija and Zapotosky 2020). On March 13, 2020, the BOP implemented Phase 2 of the BOP Action Plan (BOP, 2020c, 3/24). In Phase 2, the BOP acknowledged that the U.S. would have "more confirmed cases in the coming weeks" and noted "that the population density of prisons creates a risk of infection and transmission for inmates and staff." To ensure continued effective operations and staff safety, Phase 2 included the immediate suspension of social visits; the limitation of legal visits for 30 days; screening programs for all newly-arriving persons for exposure risk factors and symptoms; quarantining of symptomatic inmates with exposure risk factors; and testing and quarantining of symptomatic inmates with exposure risk factors, (BOP, 2020b, 3/13).

In a March 12, 2020 letter to Attorney General Barr, House Judiciary Committee Chairman Jerrold Nadler (D-NY) requested information on DOJ's handling of COVID-19 and the health and safety of those in federal prisons (Nadler 2020). Chairman Nadler highlighted the risk to vulnerable persons posed by COVID-19, particularly those with underlying health conditions, and requested that the DOJ consider measures to reduce the number of prisoners in federal custody. In a March 19, 2020 letter, Chairman Nadler and Subcommittee on Crime, Terrorism, and Homeland Security Chair Karen Bass (D-CA) reiterated the need for transparency, communication, and information on how BOP and the U.S. Marshals Service 
(USMS) were handling the COVID-19 crisis, both in protecting employees and individuals held in their custody (Nadler and Bass 2020). They suggested the DOJ consider moving courts to release vulnerable federal prisoners, including pregnant women, those 50-years-old and older, and those who suffer from chronic illnesses. They asked that the BOP immediately reassess every person with 36 months or less remaining on their sentence to determine if they could serve the last year of their sentence in community corrections and home confinement. They requested that the DOJ use its available authorities, including executive clemency, commutation, furlough, compassionate release, and parole, to reduce the number of federal prisoners and provide prompt and accurate information about the number of COVID-19 cases and fatalities in BOP and USMS contract facilities.

The Senate Amendment to H.R. 748, the CARES Act (U.S. Congress, 2020) set aside $\$ 100$ million in emergency funding for the federal prison system's COVID-19 response. The Act, signed by President Donald J. Trump on March 27, 2020, broadens the DOJ's authority to expand the cohort of prisoners who can be considered for home release, specifically the "high-risk and high-need population," and under emergency conditions to maximize the time for which the BOP is authorized to place a prisoner in home confinement under the first sentence of section 3624(c)(2) of title 18, U.S. Code. In normal circumstances, the section restricts BOP's home confinement authority to apply to prisoners who have the shorter of $10 \%$ of their term of imprisonment remaining, or six months.

In a March 26, 2020 memo, Attorney General Barr noted home confinement as potentially being more effective than imprisonment to protect inmates' health and directed the BOP to prioritize the use of various statutory authorities to place eligible inmates on home confinement who sought transfer in connection with the ongoing COVID-19 pandemic. Eligibility was based upon age and vulnerability criteria in accordance with CDC guidelines and those in low or minimum-security facilities could be given priority. Deemed ineligible would be persons who engaged in violent or gangrelated activity in prison or who incurred a violation within the last year while in BOP custody. Also excluded would be those with a risk assessment score above "minimum." Furthermore, individuals would need a "demonstrated and verifiable re-entry plan that will prevent recidivism and maximize public safety, including verification that the conditions under which the inmate would be confined upon release would present a lower risk of contracting COVID-19 than the inmate would face in his or her BOP facility." Moreover, those requesting release to home confinement would require a medical assessment to determine "risk factors for severe COVID-19" and serve a "mandatory 14-day quarantine period" before discharge. Finally, those transferred to home confinement would be subject to location monitoring services, and supervised release (Barr 2020a, 3/26).

While the March 26 memo appeared to signal that DOJ supported widespread early release for high risk populations, the elderly, those with underlying conditions, and those nearing the end of their sentence, BOP's March 31, 2020 Action Plan Phase 5 (BOP, 2020d, 3/31) applied a more stringent approach to managing the spread of the virus by further suspending social and legal visits and instituting a 14-day lockdown. The lockdown included keeping prisoners in assigned cells or quarters and working with the USMS to significantly decrease incoming movement to federal prisons (Tsioulcas, 2020). 
In the April 3, 2020 memo, Attorney General Barr directed the BOP to prioritize early release of prisoners from at least three specific federal institutions fighting major coronavirus outbreaks, and to "immediately maximize" appropriate transfers to home confinement (Barr 2020b, 4/3). While the guidance appears to give strong directives for early release, the step was seen by many as a reactive measure. As one stakeholder noted: "Barr wants priority releases of inmates to be from institutions that already are overcome by COVID-19" (Pavlo 2020b). For those deemed to be suitable candidates for home confinement under the April 3 memo, Attorney General Barr directed BOP to immediately process them for transfer and then immediately transfer them following a 14-day quarantine at an appropriate BOP facility, or, in appropriate cases subject to case-by case discretion, in the residence to which they would be transferred for home confinement. He wrote that BOP's assessment should be guided by the March 26 Memo, with the understanding that prisoners with a suitable confinement plan will generally be appropriate candidates for home confinement rather than at institutions in which COVID-19 is materially affecting operations.

On April 6, 2020 (Barr 2020c, 4/6), Attorney General Barr released yet another memo providing guidance to line prosecutors and underscoring that the BRA should remain the governing statute for pretrial detention issues. He directed DOJ to not seek detention to the same degree it would under normal circumstances - especially for those defendants who have not committed serious crimes and who pose a minor risk of flight (but no threat to the public) and who are clearly vulnerable to COVID-19. DOJ should continue, Attorney General Barr stated, to seek detention for defendants who are charged with serious crimes, and who pose a substantial risk of flight, or for defendants who would normally warrant detention under the BRA and who are not vulnerable to COVID-19. The April 6 memo left many observers wondering whether Attorney General Barr had in fact announced a different rule for line prosecutors to apply during COVID-19, or whether he merely reiterated they were to follow "business as usual."

As directed in the DOJ memos, BOP began to place eligible inmates in 14-day prerelease quarantine in preparation for their release to home confinement. In late April, the early release to home confinement for about 200 federal prisoners was suddenly stalled, when the DOJ clarified its earlier guidance to require inmates to have served at least $50 \%$ of their sentences in order to be eligible for placement in home confinement. In some cases, prisoners who had been put into pre-release quarantine, anticipating release, were suddenly deemed ineligible to be sent home after DOJ's guidance abruptly shifted to exclude them from release (Gerstein 2020a). The changing federal guidance has been described as "shifting, contradictory" (Satija and Zapotosky 2020). Following criticism, the BOP again reversed course stating the amount of time served would merely count as a "priority factor" in decisions (Satija and Zapotosky 2020). The shifting policy caused confusion across prisons and courts. Attorneys and federal judges demanded that prison officials explain their rules and criteria for releasing inmates during the pandemic and some federal judges resorted to ordering prison officials to define their policy in writing (Neff and Blakinger 2020). The BOP sent a statement to Congress expressing "regret over the lack of clarity involving inmates with more than half their sentences remaining" (Gerstein 2020b).

In a federal prison in Butner (NC), one of the federal facilities hardest hit by the virus, U.S. District Court Judge Alison Nathan criticized the BOP's 14-day quarantine 
program contending that the "illogical" and "Kafkaesque" quarantine policies put inmates and the community at greater risk of contracting coronavirus (Gerstein 2020a). Judge Nathan wrote that the BOP policy "makes it likely that inmates approved for home confinement will not be released; as the virus spreads in the unit, the 14-day clock will repeatedly restart, perpetually prolonging incarceration" (Gerstein 2020a).

In addition, BOP's reporting of infections and fatalities has been called into question as being potentially unreliable (Pavlo 2020a). The American Civil Liberties Union (ACLU) has challenged the accuracy of the BOP's reporting of COVID-19 cases. In a statement, the ACLU wrote, "the recently released numbers highlight one of the reasons jails and prisons across the country comprise 6 of the 10 largest hotspots of COVID-19 infection, putting both those who work and are incarcerated in them at increased risk of contracting this deadly disease. We believe that there are likely thousands of additional cases among officers and incarcerated people that haven't been reported because of the lack of testing" (ACLU 2020).

Even if the criticism of the BOP's reporting is correct, the numbers reported for both federal inmates as well as BOP staff point to the dire need for early release to help mitigate the spread. The tool being used by the BOP to help determine eligibility for this early release is the Prisoner Assessment Tool Targeting Estimated Risk Patterns and Needs (PATTERN). However, significantly, PATTERN was not developed for the purpose of assessing eligibility for release during a public health crisis, but rather to assess the recidivism risk of BOP inmates.

\section{The Problematics of PATTERN}

PATTERN was created as part of the First Step Act, a federal criminal justice reform bill signed into law in 2018 (U.S.C. § S.756). A key objective of the bill was the reduction of the federal prison population. To achieve this, PATTERN would be used to classify inmates as either minimum, low, medium, or high risk for recidivism. A prisoner could gain early release based on their score and they could theoretically lower their score during their term of imprisonment by participating in recidivism reduction programming. As a means to better address racial inequities often brought by traditional statistical indicators of perceived risk, dynamic indicators of conduct within prison would be incorporated into the tool's design. While the First Step Act garnered bipartisan support, critics have been skeptical of PATTERN's ability to attenuate existing disparities in the criminal justice system based on race and ethnicity (Fogliato et al. 2020; Hager 2020). Further, the fact that PATTERN has yet to be subjected to a rigorous independent evaluation has added to the controversy (ACLU 2019).

The use of actuarial risk assessment programs has been argued to produce and reinforce racial disparities in the criminal justice system (Angwin et al. 2016; Starr 2014). Critics have argued that "even when direct indicators of protected group membership, such as race and gender, are not included as predictors, associations between these measures and legitimate predictors can 'bake in' unfairness" (Berk et al. 2018). It has also been argued that even with advances in machine learning, the use of proxy variables in algorithms predicting future crime makes it "difficult to break cycles of criminalization that are driven by the iatrogenic effects of the criminal justice system itself' (Barabas et al. 2018). 
PATTERN is not dissimilar to its risk assessment predecessors and has been criticized regarding issues of racial disparity. The DOJ's internal assessment found that only $7 \%$ of black offenders would be deemed low risk, in contrast to $30 \%$ of white offenders (Hager 2020). To this end, the ACLU, along with other human rights organizations, wrote a letter to the director of the National Institute of Justice asking for an acknowledgement and correction of the racial and gender biases in PATTERN. They further called for the suspension of the program until these adjustments were made and the program was evaluated by independent experts. Without this, they feared PATTERN threatened "to significantly undermine the spirit of the law by indefinitely codifying our criminal legal system's existing racial and ethnic disparities" (ACLU 2019). Some have furthered this call warning against using the tool as the sole means of establishing who qualifies for compassionate release for COVID-19 (Fogliato et al. 2020; Hager 2020).

\section{Conclusion}

On March 28, 2020, Patrick Jones, who was serving a 27-year sentence at FCC Oakdale, Louisiana for a nonviolent drug crime became the first federal inmate to die from COVID-19. He was 49 years old. At this writing, there were 85 federal inmate deaths and one BOP staff death attributed to the disease, (BOP, 2020a).

Simply put, COVID-19 has fundamentally disrupted the U.S. corrections system. The pandemic has revealed and exacerbated systemic problems in prisons and jails, which were already viewed as amplifiers of infectious disease and are now centers of outbreaks. While DOJ and the BOP had to rapidly respond, like many agencies and organizations, to this extraordinary pandemic, the policy guidance issued to respond to the crisis often created confusion for those tasked with implementation. Unfortunately, the poorly communicated policies continue to impact personnel and inmates. As such, rigorous research in the handling of the COVID-19 pandemic in U.S. correctional systems specifically related to early release programs would provide valuable insight into necessary policy adjustments to more effectively ensure the health and safety of personnel and inmates. Research into policies and procedures implemented to contain the spread of the virus in these facilities will have grave consequences for both those behind their walls and those who cycle through them. Comprehensive pandemic policy and standard guidance that is implemented across the federal corrections system is needed to safeguard essential personnel and inmates.

Due to a myriad of mitigating factors, indicators point to a reactive and non-uniform response to early release across the nation. Because of the self-evident racial and ethnic bias within the U.S. justice system, future research should investigate not only the numbers and demographics of those released but also of those not released. Furthermore, because actuarial risk assessment programs have been criticized as playing an exacerbating factor to the levels of disproportionate minority contact with the justice system, future independent assessment of the PATTERN system is a necessity. Another area in which risk assessment tools may be advanced is by drawing on spatial diagnostic techniques that capture crime risk in the community at-large (Drawve et al. 2016). Current assessment tools disproportionately focus on person level attributes or anecdotal evidence when assessing reentry needs. Risk of crime measures for 
the communities in which individuals are returning may allow for a more precise estimate of recidivism risk and better highlight the services and resources necessary for successful reentry.

The abruptness of release and the lack of time for planning, coupled with familiar pitfalls of reentry, have led to increased rates of compassionately released inmates ending up homeless, in shelters, or sleeping in their cars during COVID-19 (Kendall and Salonga 2020). This has led to reports of some released prisoners noting that being released due to COVID-19 has been much more emotionally difficult (Newman 2020). Successful reentry is challenging under normal circumstances and future research would do well to assess the effectiveness of COVID-19 compassionate release strategies compared to traditional re-entry programs. Rapid decarceration, especially when being released into a socially distant and largely halted society, is surely not ideal for successful reentry. However, many more individuals are now being released from detention, which will be a critical natural experiment that could inform future reentry programs.

While the pandemic has created a crisis within the U.S. correctional system, it also presents an opportunity to question the utility of mass incarceration and to explore decarceration and the decades-long tough-on-crime laws, harsh sentencing, and accelerated incarceration which brought about today's era of mass incarceration. Mass incarceration, aging prison populations, and high levels of chronic illness, all conditions present before the pandemic, have merely been exacerbated by it. While we should learn from this pandemic and enact policies and procedures to enable our correctional system to better respond to future pandemics, we should also take advantage of this time to reduce some of the long-standing issues facing our correctional system.

\section{References}

Abutaleb, Y., Dawsey, J., Nakashima, E., \& Miller, G. (2020). The U.S. was beset by denial and dysfunction as the coronavirus raged. The Washington Post. Retrieved from https://www.washingtonpost. com/national-security/2020/04/04/coronavirus-government-dysfunction/?arc404=true.

Adair, D.N. Jr. (2006). The bail reform act of 1984, Third Edition. Federal Judicial Center. Retrieved from https://www.fjc.gov/sites/default/files/2012/BailAct3.pdf.

Alexander, M. (2012). The new Jim crow: Mass incarceration in the age of colorblindness. Revised edition. New York: New Press.

American Civil Liberties Union (2020). Groups also call for extreme proactive measures for most vulnerable to COVID-19 infection. ACLU. Retrieved from https://www.aclu.org/press-releases/aclu-and-councilprison-locals-call-mass-testing-all-employees-and-incarcerated.

American Civil Liberties Union (2019). Comment Letter to Department of Justice on PATTERN First Step Act. September 3rd, 2019. ACLU. Retrieved from https://civilrights.org/resource/comment-letter-todepartment-of-justice-on-pattern-first-step-act/.

Angwin, J., Larson, J., Mttu, S., \& Kirchner, L. (2016). Machine Bias: There's software used across the country to predict future criminals. And it's biased against blacks. Propublica. Retrieved from https://www.propublica.org/article/machine-bias-risk-assessments-in-criminal-sentencing.

Armstrong, G. S., \& Rodriguez, N. (2005). Effects of individual and contextual characteristics on preadjudication detention of juvenile delinquents. Justice Quarterly, 22, 521-539.

Aspinwall, C., \& Neff, J. (2020). These prisons are doing mass testing for COVID-19 - and finding mass infections. The Marshall Project. Retrieved from https:/www.themarshallproject.org/2020/04/24/theseprisons-are-doing-mass-testing-for-covid-19-and-finding-mass-infections. 
Bai, J. R., Befus, M., Mukherjee, D. V., Lowy, F. D., \& Larson, E. L. (2015). Prevalence and predictors of chronic health conditions of inmates newly admitted to maximum security prisons. Journal of Correctional Health Care, 21, 255-264.

Barabas, C., Dinakar, K., Ito, J., Virza, M., \& Zittrain, J. (2018). Interventions over Predictions: Reframing the Ethical Debate for Actuarial Risk Assessment. Proceedings of Machine Learning Research, 81, 1-15.

Barr, W.P., United States Attorney General (2020a). Prioritization of home confinement as appropriate in response to COVID-19 pandemic. U.S. Department of Justice. Retrieved from https://www.justice. gov/file/1262731/download.

Barr, W.P., United States Attorney General (2020b). Increasing use of home confinement at institutions Most affected by COVID-19. U.S. Department of Justice. Retrieved from https://www.justice.gov/file/1266661 /download.

Barr, W.P., United States Attorney General (2020c). Litigating pre-trial detention issues during the COVID-19 pandemic. U.S. Department of Justice. Retrieved from https://www.justice.gov/file/1266901/download.

Berk, R., Heidari, H., Jabbari, S., Kearns, M., \& Roth, A. (2018). Fairness in criminal justice risk assessments: The state of the art. Sociological Methods \& Research, online first., 004912411878253

Binswanger, I. A., Krueger, P. M., \& Steiner, J. F. (2009). Prevalence of chronic medical conditions among jail and prison inmates in the USA compared with the general population. Journal of Epidemiology and Community Health, 63, 912-919. https://doi.org/10.1136/jech.2009.090662.

Bridges, G. S., \& Steen, S. (1998). Racial disparities in official assessments of juvenile offenders: Attributional stereotypes as mediating mechanisms. American Sociological Review, 63, 554-570.

Carson, E.A. \& Golinelli, D. (2014). Prisoners in 2012: Trends in admissions and releases, 1991-2012. Bureau of Justice Statistics Bulletin (pp. 1-44). Washington, DC: U.S. Department of Justice.

Centers for Disease Control and Prevention (CDC). Coronavirus Disease 2019 (2020a). https://www.cdc. gov/coronavirus/2019-ncov/hcp/underlying-conditions.html.

Centers for Disease Control and Prevention (CDC). Coronavirus Disease 2019 (2020b). https://www.cdc. gov/coronavirus/2019-ncov/prevent-getting-sick/disinfecting-your-home.html.

Drawve, G., Thomas, S. A., \& Walker, J. (2016). Bringing the physical environment back into neighborhood research: The utility of RTM for developing an aggregate neighborhood risk of crime (ANROC) measure. Journal of Criminal Justice, 44, 21-29.

Fazel, S., \& Baillargeon, J. (2011). The health of prisoners. Lancet, 377, 956-965. doi:10.1016/s01406736(10)61053-7.

Federal Bureau of Prisons. (2020a). Federal Bureau of Prisons website. Retrieved from https://www.bop. gov/coronavirus/.

Federal Bureau of Prisons (2020b). Federal Bureau of Prisons COVID-19 action Plan. Agency-wide Modified Operations. Updated March 13. Retrieved from https://www.bop.gov/resources/news/20200313_covid19.jsp.

Federal Bureau of Prisons (2020c). Bureau of Prisons Update on COVID-19. Retrieved from https://www. bop.gov/resources/news/pdfs/20200324_bop_press_release_covid19_update.pdf.

Federal Bureau of Prisons (2020d). Bureau of Prisons COVID-19 Action Plan: Phase Five, Press Release. Retrieved from https:/www.bop.gov/resources/news/pdfs/20200331_press_release_action_plan_5.pdf.

Federal Emergency Management Agency (2014). Effective Communication. Student Manual. Lesson 3. Communicating in an Emergency, (pg. 3.2). Retrieved from https://raining.fema.gov/emiweb/is/is 242 b/student\%20manual/sm_03.pdf.

Fogliato, R., Xiang, A., \& Chouldechova, A. (2020). Why PATTERN should not be used: The perils of using algorithmic risk assessment tools during COVID-19. Partnership with AI. Retrieved from https://www. partnershiponai.org/why-pattern-should-not-be-used-the-perils-of-using-algorithmic-risk-assessmenttools-during-covid-19/.

Gerstein, J. (2020a) Judge rips feds over prison quarantine policies. Politico. Retrieved from https://www. politico.com/news/2020/04/20/judge-quarantine-prison-196656.

Gerstein, J. (2020b). Judge orders transfer or release for some inmates at virus-wracked Ohio federal prison. Politico. Retrieved from https://www.politico.com/news/2020/04/22/coronavirus-prisoners-released-ohiolouisiana-202953.

Gill, L. (2020). Arkansas allows employees who test positive for COVID-19 to continue working in the state's prisons. The Appeal. Retrieved from https://theappeal.org/arkansas-allows-employees-who-test-positivefor-covid-19-to-continue-working-in-the-states-prisons/.

Guetzkow, J., \& Schoon, E. (2015). If you build it, They Will Fill It: The Consequences of Prison Overcrowding Litigation. Law and Society Review, 49, 2-401.432. 
Hager, E. (2020). How bill Barr's COVID-19 prisoner release plan could favor white people. The Marshall Project. Retrieved from https://www.themarshallproject.org/2020/03/28/how-bill-barr-s-covid-19prisoner-release-plan-could-favor-white-people.

Johns Hopkins University of Medicine. (2020). COVID-19 dashboard by the Center for Systems Science and Engineering. Coronavirus resource center. Retrieved from https://coronavirus.jhu.edu/map.html.

Kendall, M., \& Salonga, R. (2020). Coronavirus: Mass jail, Prison releases leave some Bay area inmates on the streets. The Mercury News. Retrieved from https://www.mercurynews.com/2020/04/27/coronavirusmass-jail-prison-releases-leave-some-inmates-on-the-streets/.

Lauer, C., \& Long, C. (2020, March 7). US prisons, jails on alert for spread of coronavirus. Associated Press. Retrieved from https://abcnews.go.com/Health/wireStory/us-prisons-jails-alert-spread-coronavirus69437696.

Leiber, M. (2013). Race, pre- and post-detention, and juvenile justice decision making. Crime and Delinquency, 59, 396-418.

McKillop, M., \& Boucher, A. (2018). Aging Prison Populations Drive Up Costs. Pew Trusts. Retrieved from https:/www.pewtrusts.org/en/research-and-analysis/articles/2018/02/20/aging-prison-populations-driveup-costs.

Nadler, J. (2020). Chairman Nadler asks DOJ about BOP \& U.S. marshals service response to Coronavirus \& Seeks Answers Regarding Health \& safety of those in Federal Prisons. House Committee on the Judiciary. Retrieved from https://judiciary.house.gov/news/documentsingle.aspx?DocumentID=2874.

Nadler, J., \& Bass, K. (2020). Nadler \& Bass Demand Answers from DOJ about Federal Bureau of Prisons \& U.S. marshals service response to coronavirus. House Committee on the Judiciary. Retrieved from https://judiciary.house.gov/news/documentsingle.aspx?DocumentID=2885.

Neff, J., \& Blakinger, K. (2020). We cannot do this alone. The Marshall Project. Retrieved from https://www. themarshallproject.org/2020/04/25/few-federal-prisoners-released-under-covid-19-emergency-policies.

Newman, K. (2020). For prisoners released due to Covid-19, a different world awaits. US News. Retrieved from https:/www.usnews.com/news/healthiest-communities/articles/2020-04-15/prisoners-released-dueto-coronavirus-enter-a-different-world.

Park, K., Meagher, T., \& Li, W. (2020). Tracking the Spread of Coronavirus in Prisons. The Marshall Project. Retrieved from https://www.themarshallproject.org/2020/04/24/tracking-the-spread-of-coronavirus-inprisons.

Pavlo, W. (2020a) Bureau Of Prisons Underreporting COVID-19 Outbreaks In Prison. Forbes. Retrieved from https:/www.forbes.com/sites/walterpavlo/2020/04/01/bureau-of-prisons-underreporting-outbreaks-inprison/\#68f219377ba3.

Pavlo, W. (2020b) AG William Barr's Memo To Bureau Of Prisons: 'Time is of the essence'. Forbes. Retrieved from https://www.forbes.com/sites/walterpavlo/2020/04/04/ag-william-barrs-new-memo-tobureau-of-prisons-time-is-of-the-essence/\#5e 5cc3a26805.

Puzzanchera, C., \& Adams, B. (2012). National disproportionate minority contact databook. Developed by the National Center for juvenile justice for the Office of Juvenile Justice and Delinquency Prevention. Retrieved from http://ojjdp.ncjrs.gov/ojstatbb/dmcdb/.

Satija, N., \& Zapotosky, M. (2020). Amid coronavirus pandemic, federal inmates get mixed signals about home-confinement releases. Washington Post. Retrieved from https:/www.washingtonpost. com/investigations/amid-coronavirus-pandemic-federal-inmates-get-mixed-signals-about-homeconfinement-releases/2020/04/24/0bbc5458-84de-11ea-a3eb-e9fc93160703_story.html.

Sawyer, W. \& Wagner, P. (2020). Mass incarceration: The whole pie 2020. Prison Policy Initiative. Retrieved from https://www.prisonpolicy.org/reports/pie2020.html.

Simpson P.L., M. Simpson, A. Adily, L. Grant, \& T. Butler (2019). Prison cell spatial density and infectious and communicable diseases: a systematic review. BMJ Open, E026806. Doi: https://doi.org/10.1136 /bmjopen-2018-026806.

Skarupski, K. A., Gross, A., Schrack, J. A., Deal, J. A., \& Eber, G. B. (2018). The health of America's aging prison population. Epidemiologic Review, 40, 157-165.

Starr, S. (2014). Sentencing, by the numbers. The New York Times. Retrieved from https://www.nytimes. com/2014/08/11/opinion/sentencing-by-the-numbers.html.

Sullivan, D. (2018). S.756 - First Step Act of 2018. No: 115-391. Retrieved from https://www.congress. gov/115/plaws/pub1391/PLAW-115pub1391.pdf and https://www.congress.gov/bill/115thcongress/senate-bill/756?q=\%7B\%22search $\% 22 \% 3 \mathrm{~A} \% 5 \mathrm{~B} \% 22 \mathrm{~s} 756 \% 22 \% 5 \mathrm{D} \% 7 \mathrm{D} \& \mathrm{~s}=1 \& \mathrm{r}=1$.

Thomas, S. A., Moak, S. C., \& Walker, J. T. (2013). The contingent effect of race in juvenile court detention decisions: The role of racial versus symbolic threat. Race and Justice, 3, 239-265. 
Tsioulcas, A. (2020). Prisoners across U.S. will be confined for 14 days to cut coronavirus spread. National Public Radio. Retrieved from https:/www.npr.org/sections/coronavirus-live-updates/2020/03/31 /824917318/prisoners-across-country-will-be-confined-for-14-days-to-cut-coronavirus-spread.

Williams, T., Weiser, B., \& Rashbaum, W.K. (2020). Jails are petri dishes': Inmates freed as the virus spreads behind bars. New York Times. Retrieved from https://www.nytimes.com/2020/03/30/us/coronavirusprisons-jails.html.

United States Congress. (2020). The Coronavirus Aid, Relief, and Economic Security Act (CARES Act). Retrieved from https://www.congress.gov/bill/116th-congress/senate-bill/3548/text.

Publisher's Note Springer Nature remains neutral with regard to jurisdictional claims in published maps and institutional affiliations.

Leola A. Abraham MFA is the Associate Director, Communications in American University's Justice Programs Office. She is a senior communications practitioner with 20 years of professional experience delivering communications strategies to elevate environmental, social justice, and criminal justice issues and policies. She has delivered communications products for federal agencies. She is an associate editor of the Drug Court Review academic journal (issues II and III).

Timothy C. Brown is an Associate Professor in the Department of Sociology at San Diego State University. His research focuses on the role individual, social, and environmental inequalities have in criminality, victimization, and navigating the criminal justice system. His recent research has been accepted at Policing Quartely, Journal of Criminal Justice, Journal of Interpersonal Violence, and the Journal of Correctional Healthcare.

Shaun A. Thomas is an Associate Professor and Co-Director of the Center of Social Research in the Department of Sociology and Criminology at the University of Arkansas. His recent research has focused on neighborhood level spatial and temporal patterns in crime, institutional isolation, disproportionate minority contact, and investigating the structural and cultural sources of interpersonal violence. His recent publications have appeared in the Journal of Criminal Justice, Homicide Studies, Crime and Delinquency, Deviant Behavior, and Journal of Interpersonal Violence.

\section{Affiliations}

\section{Leola A. Abraham ${ }^{1} \cdot$ Timothy C. Brown ${ }^{2} \cdot$ Shaun A. Thomas ${ }^{3}$}

1 School of Public Affairs, American University, Washington, D.C, USA

2 Department of Sociology, San Diego State University, San Diego, CA, USA

3 Department of Sociology \& Criminology, University of Arkansas, Fayetteville, AR, USA 